\title{
Article \\ Byzantine Churches in Albania: How Geometry and Architectural Composition Influence the Acoustics
}

\author{
Silvana Sukaj ${ }^{1}$ (D) Antonella Bevilacqua ${ }^{2}$ (D), Gino Iannace ${ }^{3, *(D)}$, Ilaria Lombardi ${ }^{4}$, Rosaria Parente ${ }^{5}$ (D) \\ and Amelia Trematerra ${ }^{3}$ D
}

check for updates

Citation: Sukaj, S.; Bevilacqua, A.; Iannace, G.; Lombardi, I.; Parente, R.; Trematerra, A. Byzantine Churches in Albania: How Geometry and

Architectural Composition Influence the Acoustics. Buildings 2022, 12, 280. https://doi.org/10.3390/buildings 12030280

Academic Editor: Luca Pelà

Received: 30 January 2022

Accepted: 23 February 2022

Published: 1 March 2022

Publisher's Note: MDPI stays neutral with regard to jurisdictional claims in published maps and institutional affiliations.

Copyright: (C) 2022 by the authors. Licensee MDPI, Basel, Switzerland. This article is an open access article distributed under the terms and conditions of the Creative Commons Attribution (CC BY) license (https:// creativecommons.org/licenses/by/ $4.0 /$ )
1 Department of Engineering and Architecture, European University of Tirana (UET), 1000 Tirana, Albania; silvana.sukaj@uet.edu.al

2 Department of Industrial Engineering, University of Parma, 43124 Parma, Italy; antonella.bevilacqua@unipr.it

3 Department of Architecture and Industrial Design, University of Campania "Luigi Vanvitelli", 81031 Aversa, Italy; liatrematerra@libero.it

4 Department of Engineering, University of Campania "Luigi Vanvitelli", 81031 Aversa, Italy; ilaria.lombardi@unicampania.it

5 Benecon University Consortium, 80138 Naples, Italy; rosaria.parente@benecon.it

* Correspondence: gino.iannace@unicampania.it

\begin{abstract}
The Byzantine churches built between the 7th and the 15th centuries represent an architectural typology that has been developed along with other architectural styles. The evolution of the interior organization, to be composed of only a single nave for the oldest architecture and then developed with additional lateral naves, is one of the multiple aspects that characterizes this building type, studied mainly from an architectural perspective. The variety of roof morphology, being flat, double slope, vaulted or domed, contributes to determining the overall acoustics. This paper deals with the analysis of the acoustic characteristics related to five Byzantine churches located in Albania, specifically in Berat and Cete. A comparison of the impulse response (IR) measured inside each church was given by analyzing the most appropriate acoustic parameters and in line with ISO 3382. The acoustic surveys were undertaken with a minimal furniture and without any audience. The results highlight small difficulties in terms of speech understanding, especially under a speech clarity index found to be below the optimal range limit. This shortfall is attributed to the geometry of the volumes and to the reflecting materials applied to the surfaces that facilitate the build-up of sound energy.
\end{abstract}

Keywords: Byzantine church; acoustic measurements; architectural acoustics; church in Albania

\section{Introduction}

The geographical position of Albania falls in the middle land located between the two Roman Empires, having the capital cities in Rome (west) and Istanbul (east). From a religious perspective, the spreading of the Christianism, although under cover during the first centuries AC, was strong in the Western Roman Empire, while the Eastern Roman Empire was mainly influenced by the Orthodoxy [1].

As such, the mixture of the two religions became strong in 731 when Albania was elected as part of the patriarchalism of Constantinople (the alternative name of Byzantium, nowadays Istanbul) [1]. Thereafter, the Balkan peninsula was controlled by the Venetian dominion until the 14th century, when Venice was one of the four maritime republics that managed the commercial trading with Asians, including the Chinese [2]. During this period the Catholic beliefs in Albania were closer to the Greek rituals, until 1478, when the Turkish invasion obliged the local habitants to undergo a religious conversion, specifically to the Ottoman faith [3]. The instability took place until the 20th century when Albania was declared an atheist country, precisely in 1967. Only after 1992 could the Catholic bishops give masses and undertake prayers publicly in churches. 
The spatial compositions of Byzantine churches, which could be considered simple with the volume of a single-nave, and more complex for the multi-nave design and the introduction of domes, have been subject to extensive analyses from an architectural perspective [4]. The acoustics of the Byzantine churches matter for the late reflections due to the curved surfaces and to the reflecting materials applied to walls (plaster) and the floor (tiles), other than for the concave architectural elements (domes) that can unbalance the distribution of the sound waves across the volume [5-11].

This paper deals with the acoustic analysis of five Byzantine churches located in Albania and built during the 7th and 15th centuries [12]. Acoustic measurements carried out in different campaigns allowed the authors to compare the most appropriate acoustic parameters as outlined by ISO 3382 [13].

The geometry and the volume shape contribute to determining the direction of the sound rays, in combination with the poor level of absorption found at the finish materials [14].

The investigation was undertaken on five Byzantine churches with different volume sizes. Future research studies would introduce the digital models of the architecture herein selected to study some acoustic treatments that can be assessed before being tested on site.

\section{Typology Plan Development between 7th and 15th Centuries}

According to the literature, two main types of buildings have been developed for Byzantine churches: the structure based on a single nave and on multiple naves (called basilica) [15]. In addition, a third planning configuration appeared between the 11th and 12th century, identified as the cross shape surmounted by a dome in the center of the main volume [15].

The Byzantine churches are recognizable by some specific architectural elements, including their type of roof, that could comprise of a double slope composed of wooden beams and/or trusses, the vaulted closure and the dome usually located in the center of the cross-shaped plan layout [15].

The churches with a single nave are characterized by a rectangular plan, having a round apse on the eastern side wall [16]. The addition of lateral naves (configured as a basilica) is typical of the Hellenistic period (9th-11th century), by having the central nave higher and covered by wooden trusses [16]. The use of the barreled vault has been taking place to reduce the risks of fire that could be caused by candles used to highlight the indoor spaces. The sloped roof used for the basilica should also be contextualized in terms of financial availability, that was sometimes limited and dug to have a flat wooden ceiling in place [17].

The development of a cross-shaped plan is typical of the Mediterranean influence, characterized by a dome at the center of the axes [16]. In this type of plan configuration, the apse could be only one behind the altar, or three, located at the end of each edge of the cross except the entrance [17].

Besides these three main categories, in Albania there are also buildings that do not meet these architectural criteria and reach specific solutions dictated by other influence, as illustrated in Figure 1. This is the case of St Nicholas's church of Mesopotam, extensively analyzed in Section 2.

All the spatial typologies are shown in Figure 1. 


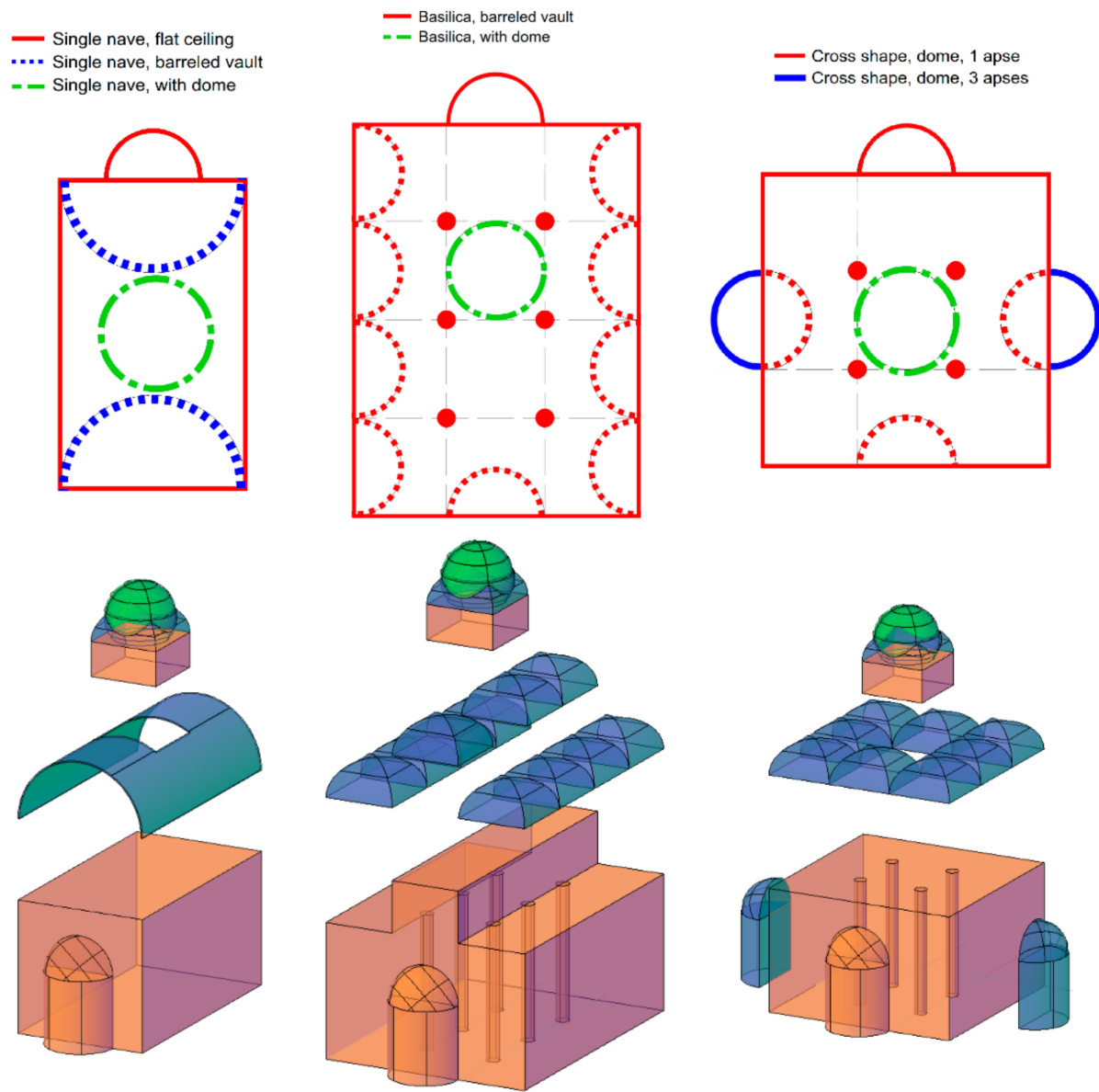

Figure 1. Drawn not to scale, different typologies of Byzantine churches. Plan layout (above) and 3D view (below).

\section{History and Architectural Features}

\subsection{St Mary Assumption's Church of Berat}

St Mary Assumption's sanctuary was built in Berat in 1797. This church is considered the building most representative of post-Byzantine architecture [8]. Based on archaeological studies, this church was built upon the foundations of an old church of reduced dimensions. In fact, the sacred estate is bounded by residential properties on four sides $[18,19]$.

The construction elements of St Mary Assumption's church follow the rules of the basilica as a reference building type, having the internal dimensions equal to $21 \mathrm{~m}$ and $11.5 \mathrm{~m}(\mathrm{~L}, \mathrm{~W})$. Additional structures have been added to the main hall, in particular a double-height porch on the west side and a narthex on the east side composed of columns and arches.

The entire volume is divided into three naves by two rows of columns running along the longitudinal axis. The central nave is characterized by two domes, with the central one hemispherical. Whereas the space defined by the columns is rectangular in plan, the vaults are elliptical. The hemispherical dome is maximum $9.5 \mathrm{~m}$ high at the center, increasing the entire volume to approximately $1800 \mathrm{~m}^{3}$. Figure 2 reports the plan and the transversal section of St Mary Assumption's church.

The church is highlighted by natural light from small windows placed in the domes and by lateral windows built in the lateral walls [20]. The walls are composed of stone blocks up to $0.8 \mathrm{~m}$ high, and of bricks which are a lighter material for the elevated structure $[21,22]$. The interior design is composed of plastered walls and a roof, and tiles on the floor. Figure 3 shows some views of the St Mary Assumption's church. 

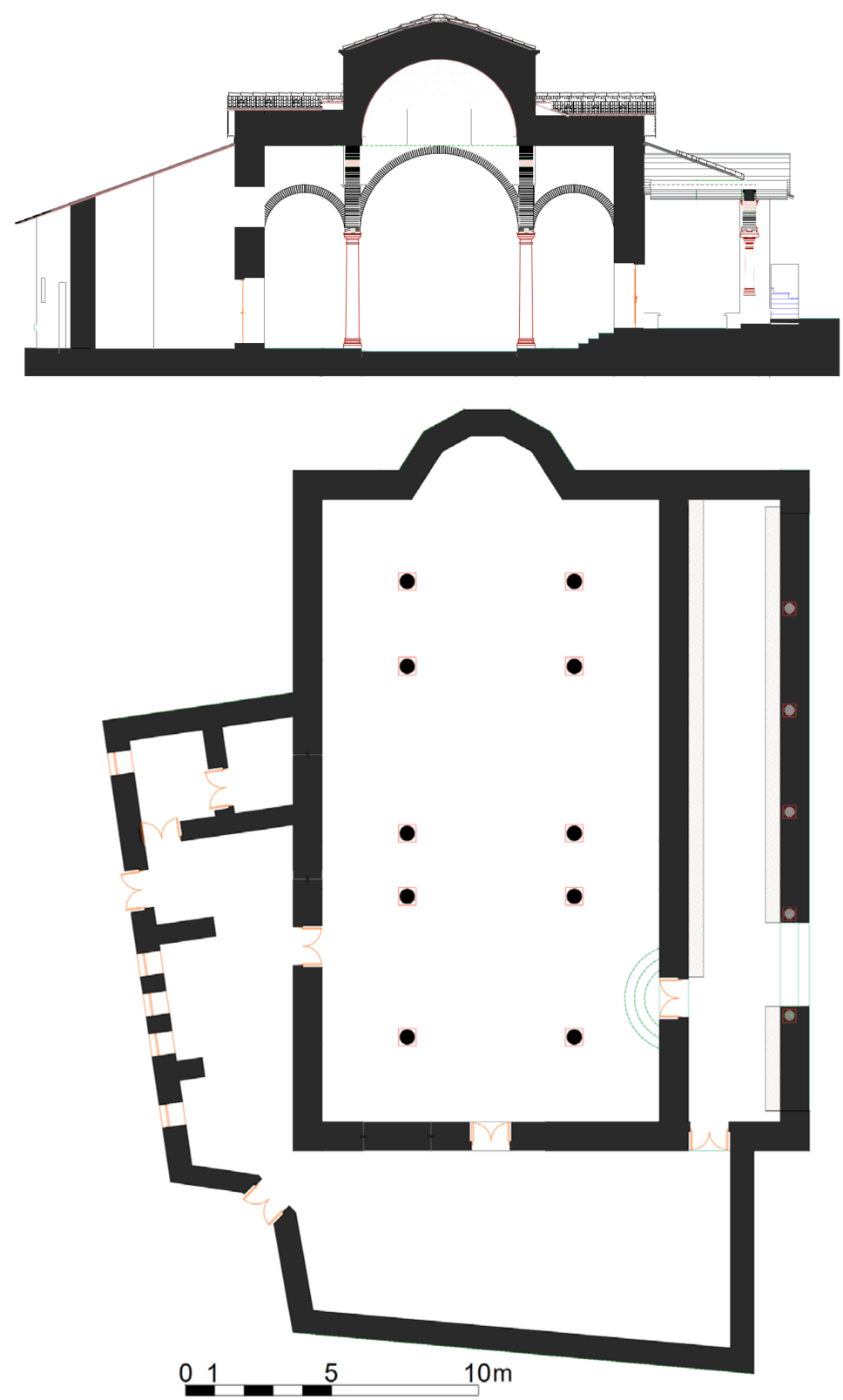

Figure 2. Plan layout and transversal section of St Mary Assumption's church. Provision courtesy of Arch. Arsim Murseli, UBT University, Pristina, Kosovo.
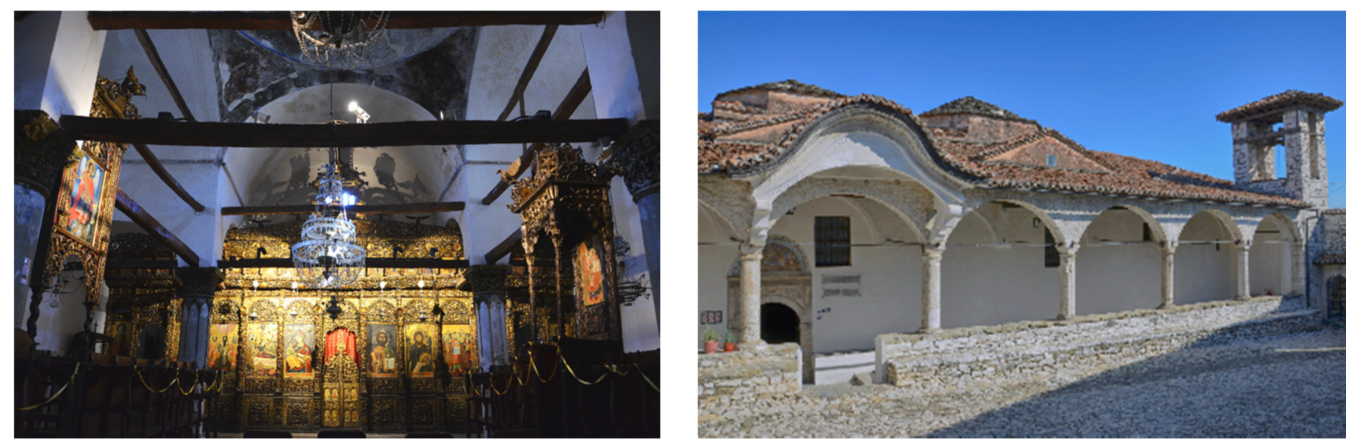

Figure 3. Internal (left) and external (right) views of the St Mary Assumption's church of Berat. 


\subsection{St Paraskevi's Church of Cete}

St Paraskevi's church was built during the 13th century in Cete, a village on the eastern side of Kavaja. The church is composed of a unique nave where the altar is placed in a squared apse. Initially there was a wooden structure separating the altar from the nave, which now no longer exists [23,24].

Based on the workmanship of the walls, the church was realized by the human resources available in the village, sometimes to be extracted by the lower classes of society and who were not experts of this work. As such, the lack of expertise regarding construction techniques determined the dimensions of width and length, which do not reflect the Romanic-gothic style of that period.

The wooden roof provided with a double slope was restored in 1963. The internal dimensions of the plan layout are equal to $14 \mathrm{~m}$ and $5.1 \mathrm{~m}(\mathrm{~L}, \mathrm{~W})$, having a total volume of approximately $460 \mathrm{~m}^{3}$ when including the apse. The northern side is provided with three windows which highlight the room, while on the southern side a porch composed of seven arches represents a sort of narthex, to be preceding the main hall $[25,26]$. Figure 4 shows the plan and the longitudinal section of St Paraskevi's church.

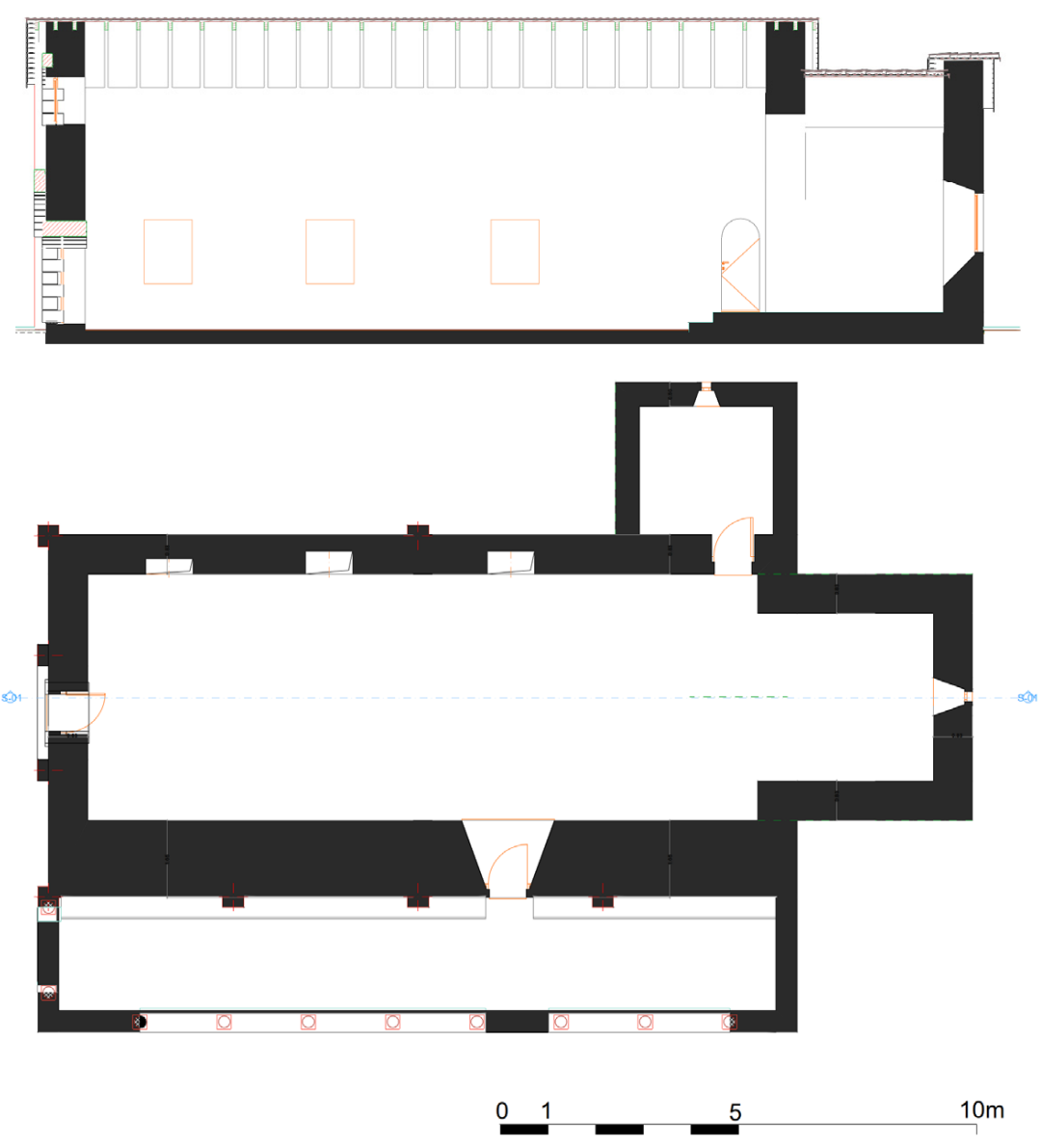

Figure 4. Plan layout and longitudinal section of St Paraskevi's church in Cete. Provision courtesy of Arch. Arsim Murseli, UBT University, Pristina, Kosovo.

The original frescos on the walls inside the church are still preserved. The interior design follows the representation of the Bible, while the stone blocks are left to be visible, as shown in Figure 5.

\subsection{St Nicholas Monastery of Mesopotamia}

St Nicholas's church as part of the fortified monastery was built in 1224 on top of a hill circumscribed by two riverbeds of the Bistrica. The architectural characteristics are typical 
of the Byzantine style, composed of only one volume divided by columns. Originally, this church was composed of two altars placed on opposite sides, for both Christian and Orthodox rituals [27-29]. Only in 1793 was the round apse built on one side.

The roof is characterized by four domes. The internal dimensions are equal to $11 \mathrm{~m}$ and $16.5 \mathrm{~m}(\mathrm{~L}, \mathrm{~W})$, having a total volume of approximately $1700 \mathrm{~m}^{3}$. Figure 6 shows the plan and the longitudinal section of St Nicholas's church.
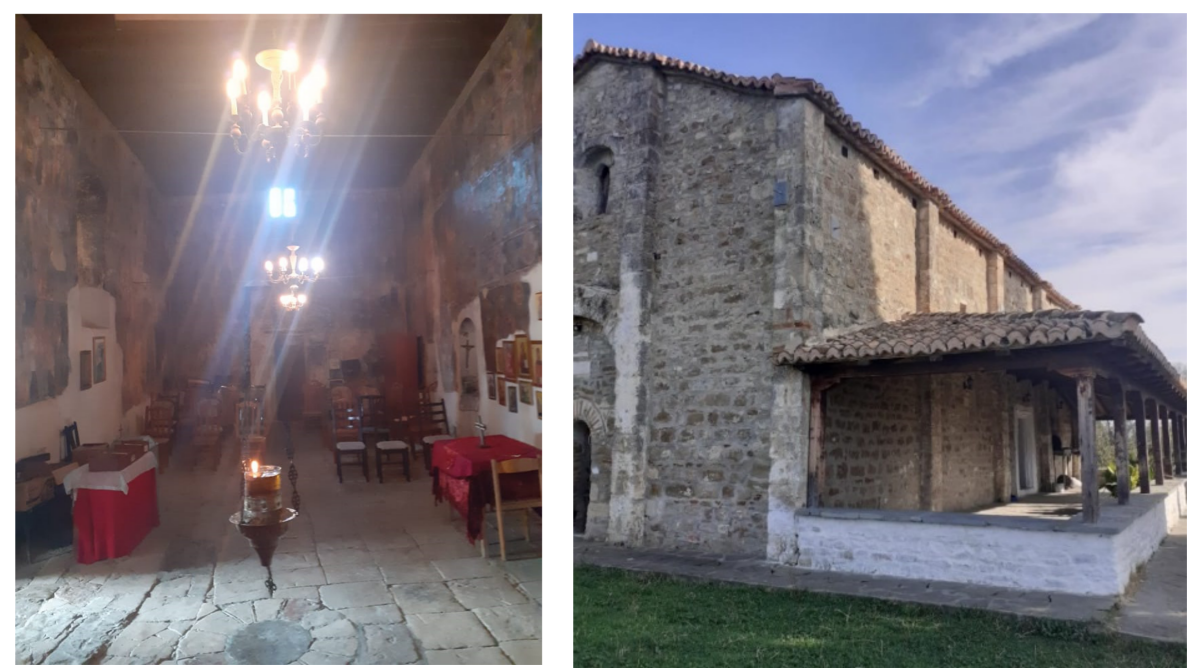

Figure 5. Internal (left) and external (right) view of St Paraskevi's church of Cete.
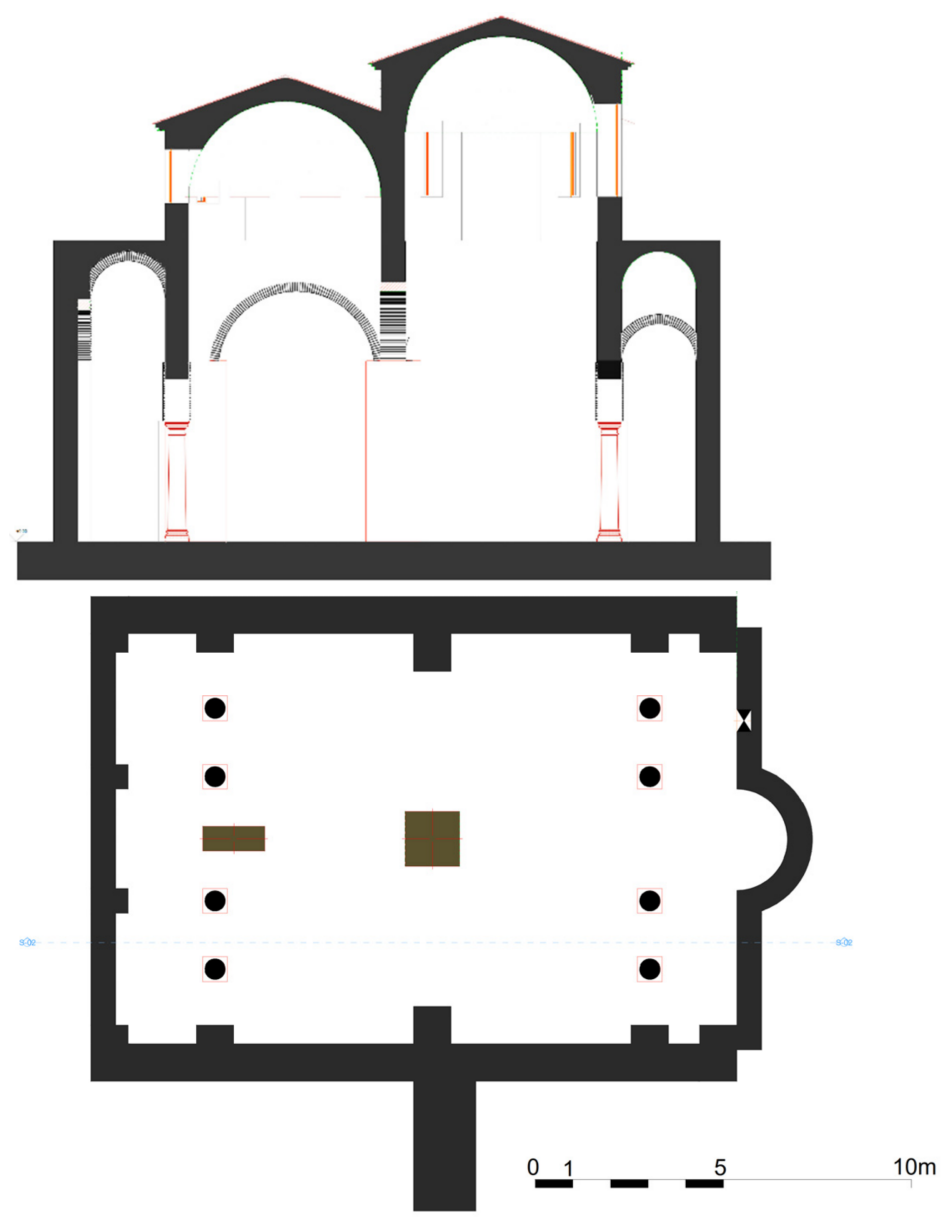

Figure 6. Plan layout and longitudinal section of St Nicholas's church of Mesopotamia. Provision courtesy of Arch. Arsim Murseli, UBT University. 
The maximum height of the biggest dome is $13.5 \mathrm{~m}$. The construction technique is identified in the clausonage, composed of slim bricks [30,31], while the basement is composed of squared stone blocks, as represented in Figure 7.
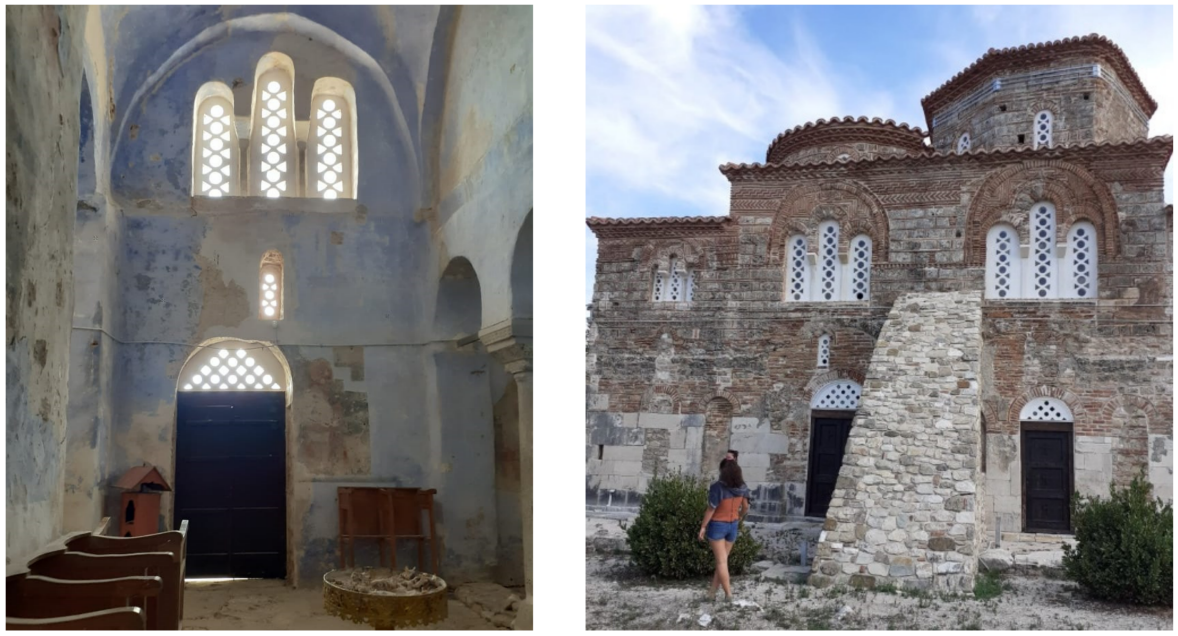

Figure 7. Internal (left) and external (right) views of St Nicholas's church of Mesopotamia.

\subsection{Holy Trinity's Church of Berat}

The Holy Trinity's church of Berat has been introduced into the list of UNESCO to become one of the cultural heritage subjects to be protected for future generations. The Byzantine church is located in the Kalaja district of the city, and it is characterized by a crossshaped plan layout with equal length of the wings. At the junction of the wings there is a hemicircular dome highlighted by four windows opened in the octagon parallelepiped [32].

An inscription honored to Andronicus Paleologus, the governor of Berat between 1302 and 1326, indicates that the church mast was built between the end of the 13th century and the first half of the 14 th.

The plan layout corresponds to a square having the dimension of the edge equal to $5.8 \mathrm{~m}$, while the entire volume is approximately $300 \mathrm{~m}^{3}$. Figure 8 shows the plan and the longitudinal section of the Holy Trinity's church.

The dome is $10 \mathrm{~m}$ high at its center. The interior design is characterized by two columns supporting capitals reused from classical ruins [33]. The layout is composed of a cross having wings of the same length, as shown in Figure 9.

\subsection{St Mary of Blachernae Church of Berat}

St Mary of Blachernae's church was built during the 13th century and in Berat it is well known for its frescos decorating all the interior walls. The name calls out the homonymous palace of Constantinople, and it is very likely that the church was built on existing foundations of the 5th century. The paintings belonging to the 16th century were realized by Nicholas Onufri [34,35].

The internal dimensions are equal to $6.6 \mathrm{~m}$ and $6 \mathrm{~m}(\mathrm{~L}, \mathrm{~W})$, having a total volume of approximately $234 \mathrm{~m}^{3}$. Figure 10 represents the plan and the longitudinal section of St Mary of Blachernae's church.

The maximum height is $5.9 \mathrm{~m}$. The interior design is characterized by two stone pillars supporting the frames of the apse [36]. All the walls are decorated with frescos belonging to the 13th century, that are partially damaged by the humidity absorbed by the walls, as shown in Figure 11.

\subsection{Overview of the Churches' Characteristics}

From the previous information it can be noticed that only St Mary Assumption's church is composed of three naves. A comparison of the architectural characteristics has been made for all the churches, as indicated in Table 1. 


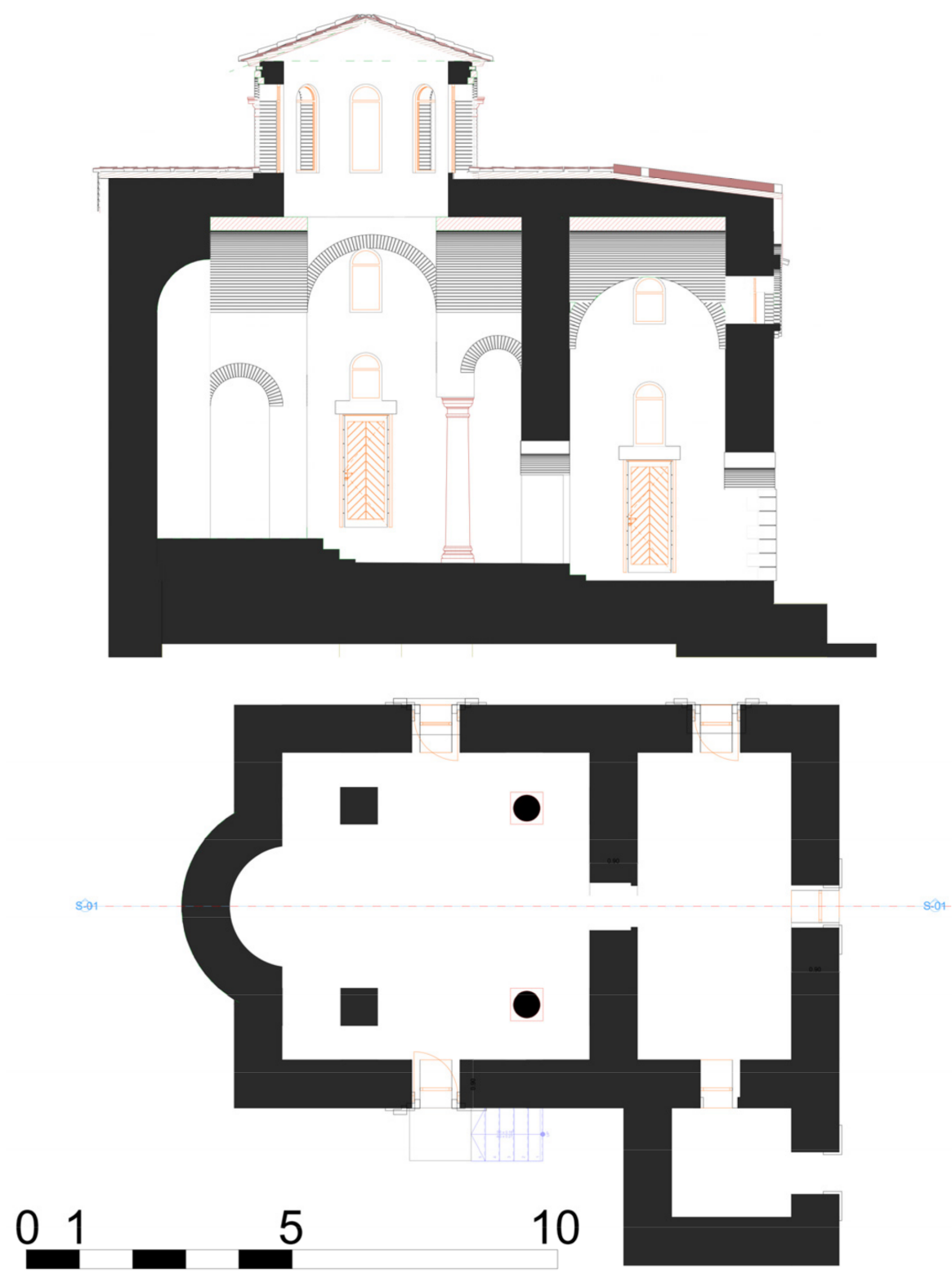

Figure 8. Plan layout and longitudinal section of the Holy Trinity's church of Berat. Provision courtesy of Arch. Arsim Murseli, UBT University.
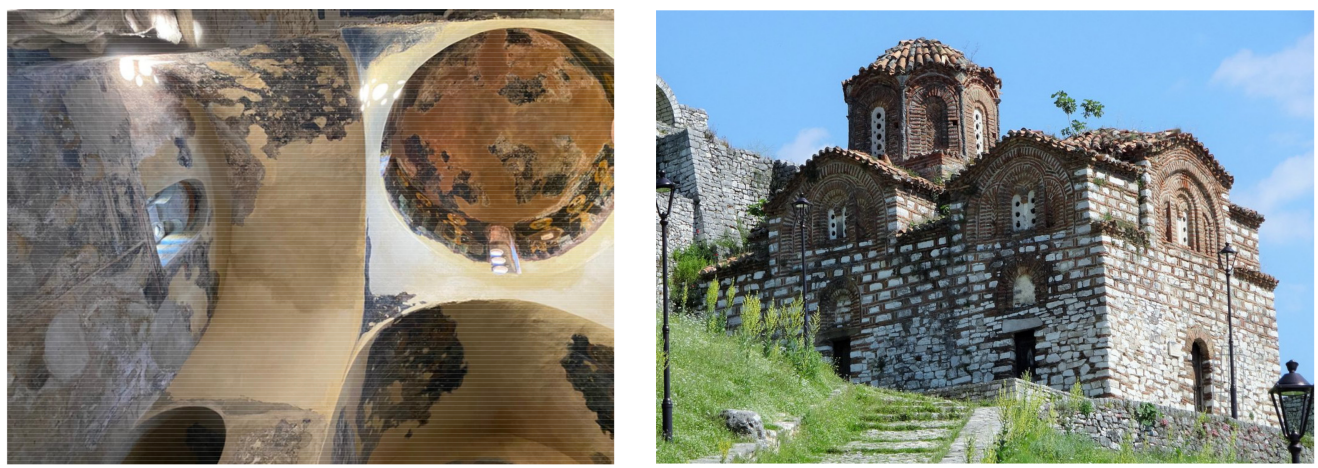

Figure 9. Internal (left) and external (right) views of the Holy Trinity's church of Berat. 

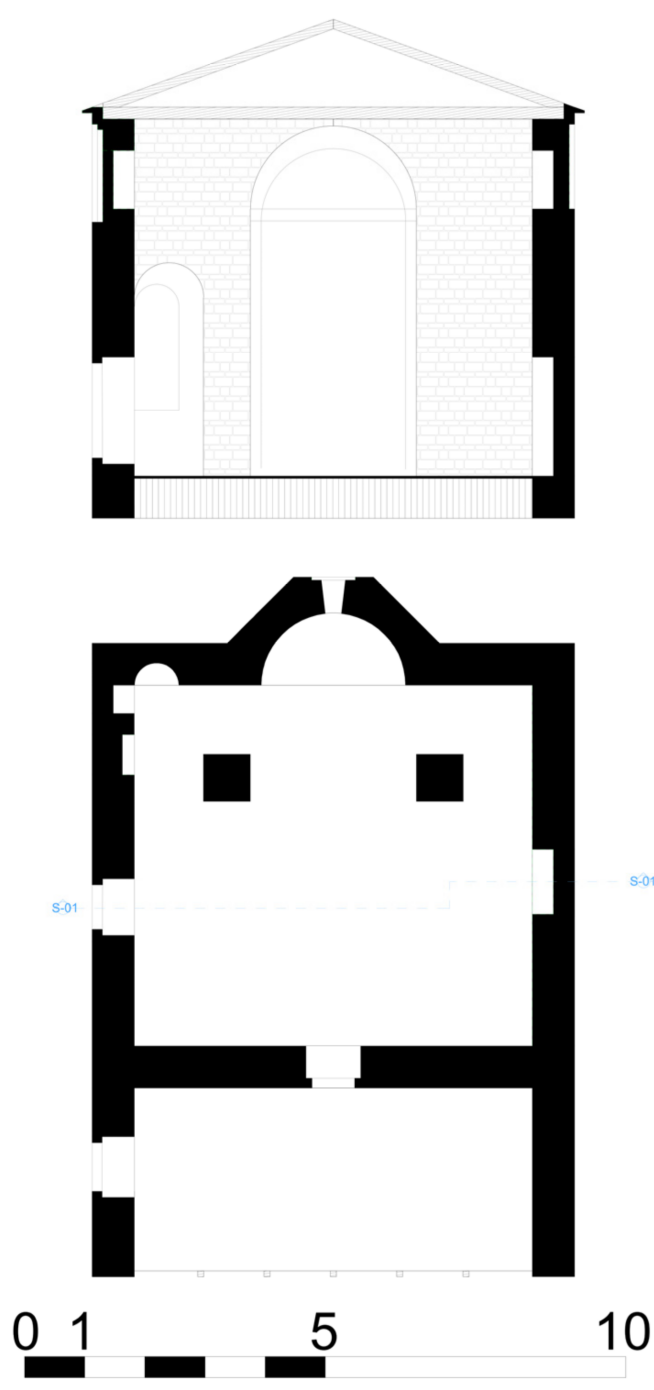

Figure 10. Plan layout and longitudinal section of the St Mary of Blachernae's church of Berat. Provision courtesy of Arch. Arsim Murseli, UBT University.
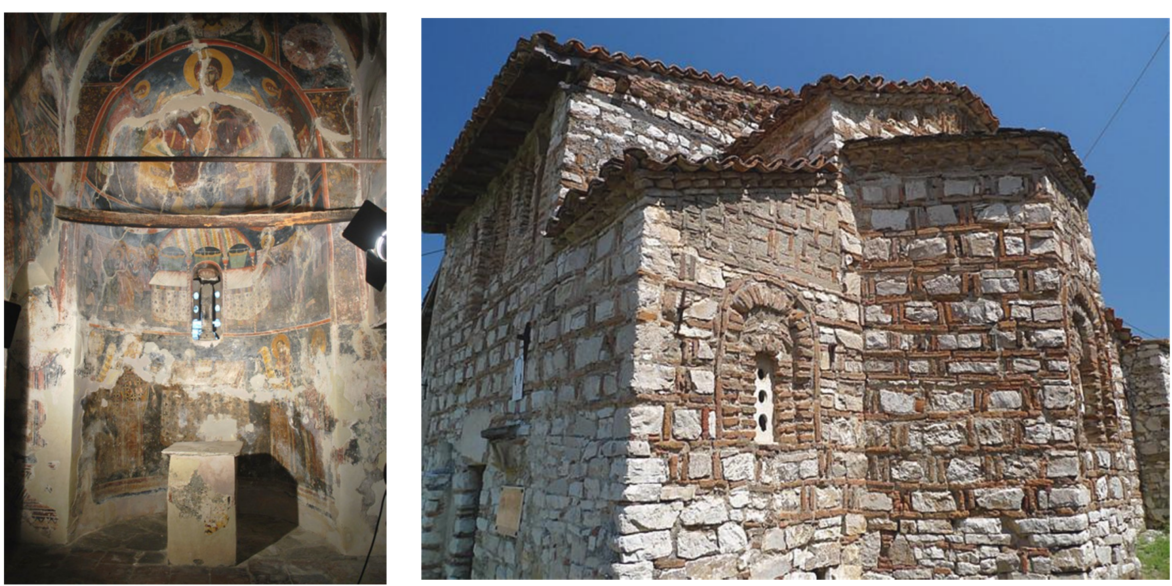

Figure 11. Internal (left) and external (right) views of St Mary of Blachernae's church of Berat. 
Table 1. Architectural characteristics of the Albanian churches in Byzantine style.

\begin{tabular}{cccccc}
\hline Description & Assumpt. & St Parask. & St Nich. & Holy Trinity & Blachernae \\
\hline $\begin{array}{c}\text { Internal } \\
\text { dimensions }(\mathrm{m})\end{array}$ & $21 \times 11.5$ & $14 \times 5.1$ & $11 \times 16.5$ & $5.8 \times 5.8$ & $6.6 \times 6$ \\
Maximum & 9.5 & 6.4 & 13.5 & 10 & 5.9 \\
height $(\mathrm{m})$ & 1800 & 460 & 1750 & 300 & 234 \\
Total volume $\left(\mathrm{m}^{3}\right)$ & & &
\end{tabular}

The finish materials of all the churches are very similar: tiles on the floor and plaster (sometimes frescos) on the walls and roof.

\section{Acoustic Surveys}

Acoustic measurements were carried out inside the churches to analyze the main acoustic parameters according to ISO 3382 [13]. The following equipment was used:

- Balloon pops (Qualatex, Wichita, KS, USA);

- Omnidirectional microphone (Bruel \& Kjaer 4165, Darmstadt, Germany).

The balloon pops are characterized by uncertainties of repeatability and directivity, although they are widely used in building acoustics tests [37]. The choice determined by the authors fell onto practical needs, to have the church unprovided of an electrical system. The balloon diameter was selected to be at least $0.5 \mathrm{~m}$ wide to abundantly cover the lower octaves of the spectrum [38]; however, the frequency bands which were to be assessed reflected the voice of the priests. The bandwidth used for the acoustic parameters ranged between $125 \mathrm{~Hz}$ and $4 \mathrm{kHz}$ [39].

In each church, the sound source was placed in two locations: in the apse, corresponding to the position of the priests during sermons, and in the middle of the nave. The balloons were burst at a $1.4 \mathrm{~m}$ height. The microphone was moved into five positions across the naves, to be $1.4 \mathrm{~m}$ high. Figure 12 shows the equipment positions during the survey.

The acoustic measurements were undertaken without any audience [40]. The main acoustic parameters being assessed were the early decay time (EDT), reverberation time $\left(\mathrm{T}_{20}\right)$, clarity index $\left(\mathrm{C}_{50}\right)$, definition $\left(\mathrm{D}_{50}\right)$, and speech transmission index (STI). 


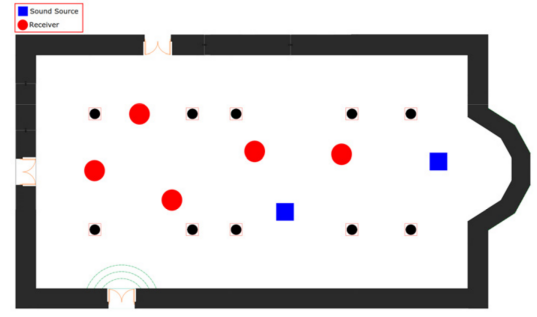

(a)

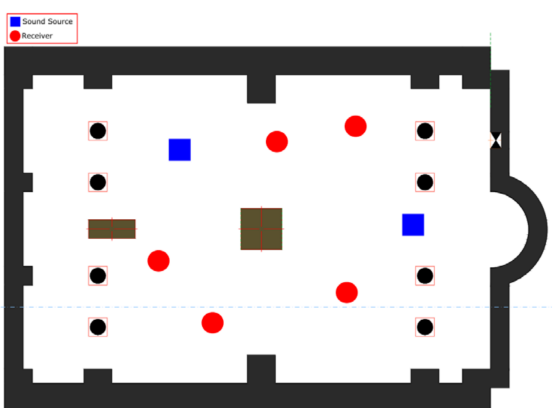

(c)

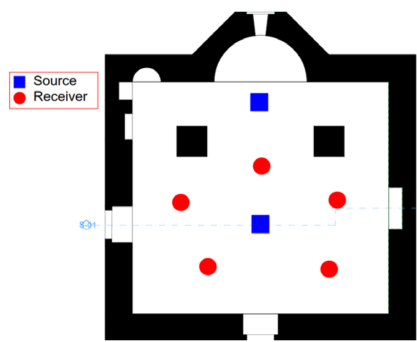

(e)

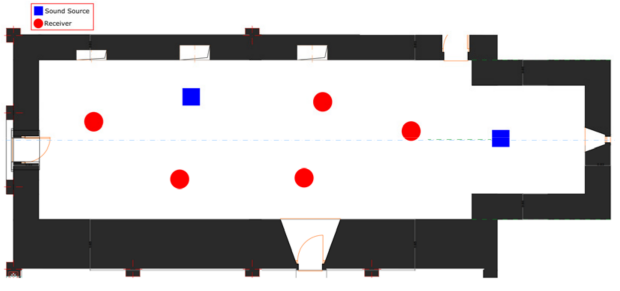

(b)

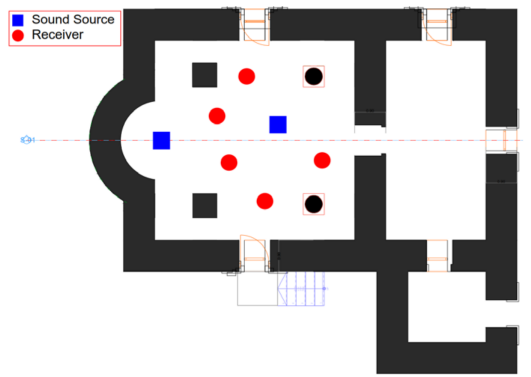

(d)

Figure 12. Location of the equipment during the acoustic measurement inside the five churches: St Mary Assumption's of Berat (a), St Paraskevi's of Cete (b), St Nicholas's of Mesopotamia (c), Holy Trinity's church of Berat (d), St Mary of Blachernae's of Berat (e).

\section{Measured Results}

The values obtained by analyzing the impulse responses (IRs) have been arithmetically averaged over all the measuring positions.

Figures 13-17 show the main acoustic parameters represented in different graphs where the spectrum bandwidth ranges between $125 \mathrm{~Hz}$ and $4 \mathrm{kHz}$.

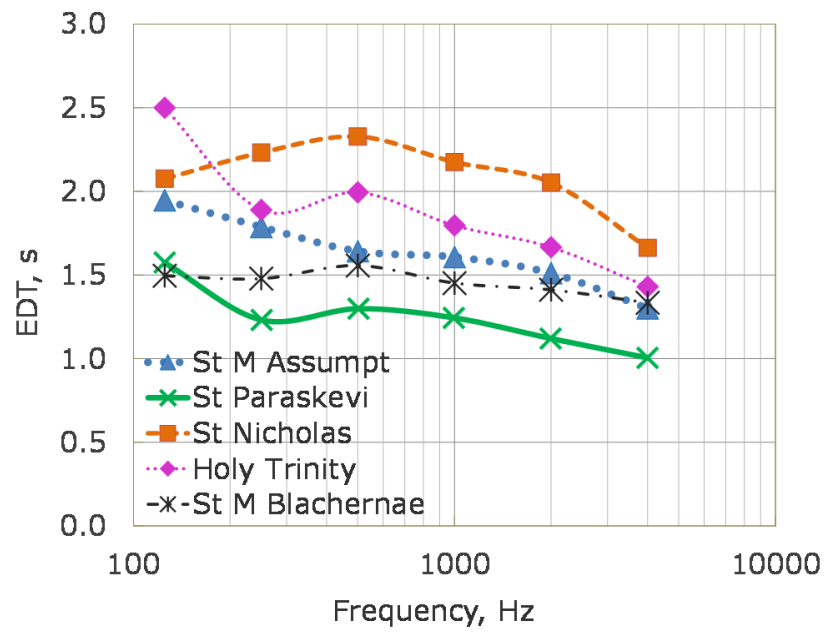

Figure 13. Measured results of early decay time (EDT). 


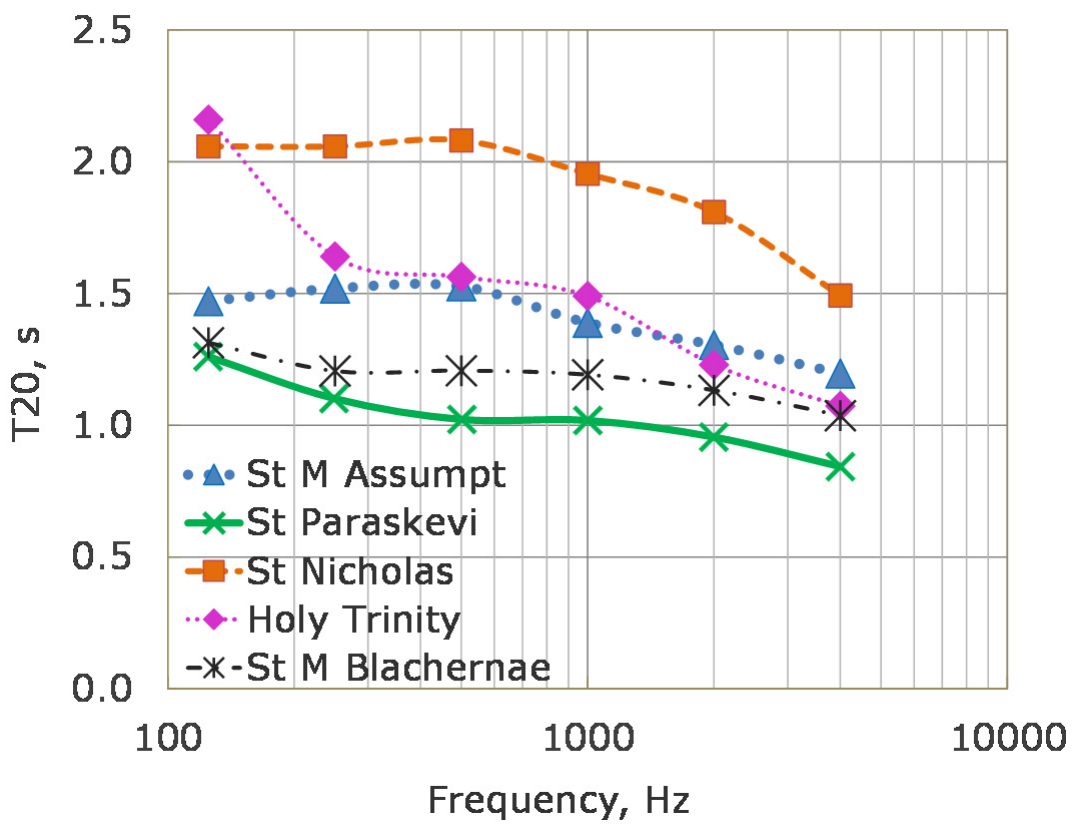

Figure 14. Measured values of reverberation time $\left(\mathrm{T}_{20}\right)$.

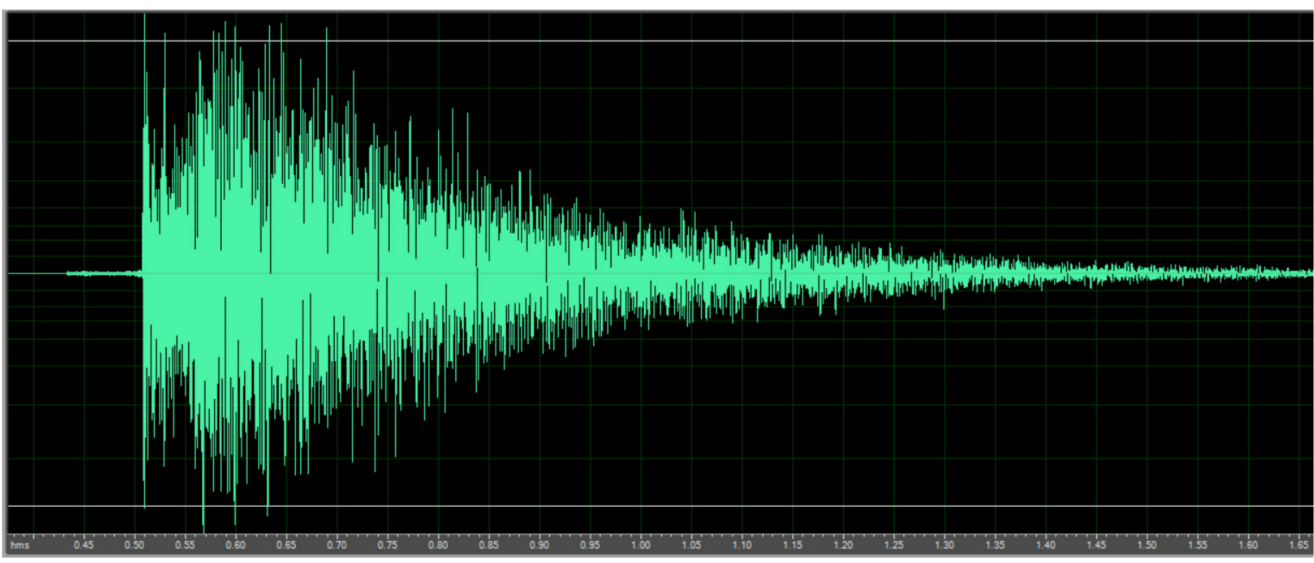

Figure 15. Impulse response measured inside St Nicholas's church.

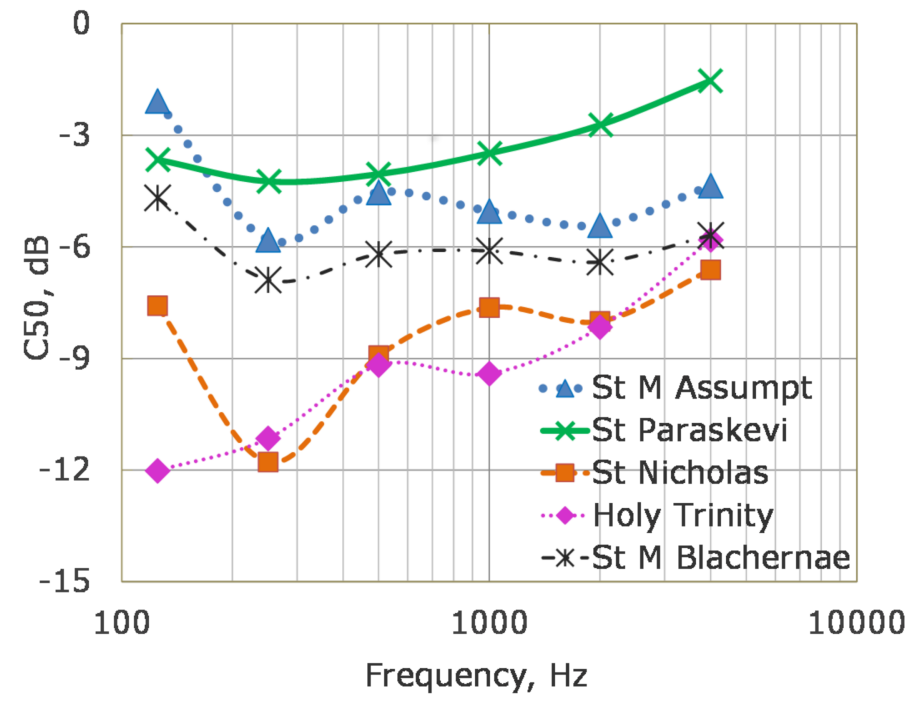

Figure 16. Measured results of clarity index $\left(\mathrm{C}_{50}\right)$. 


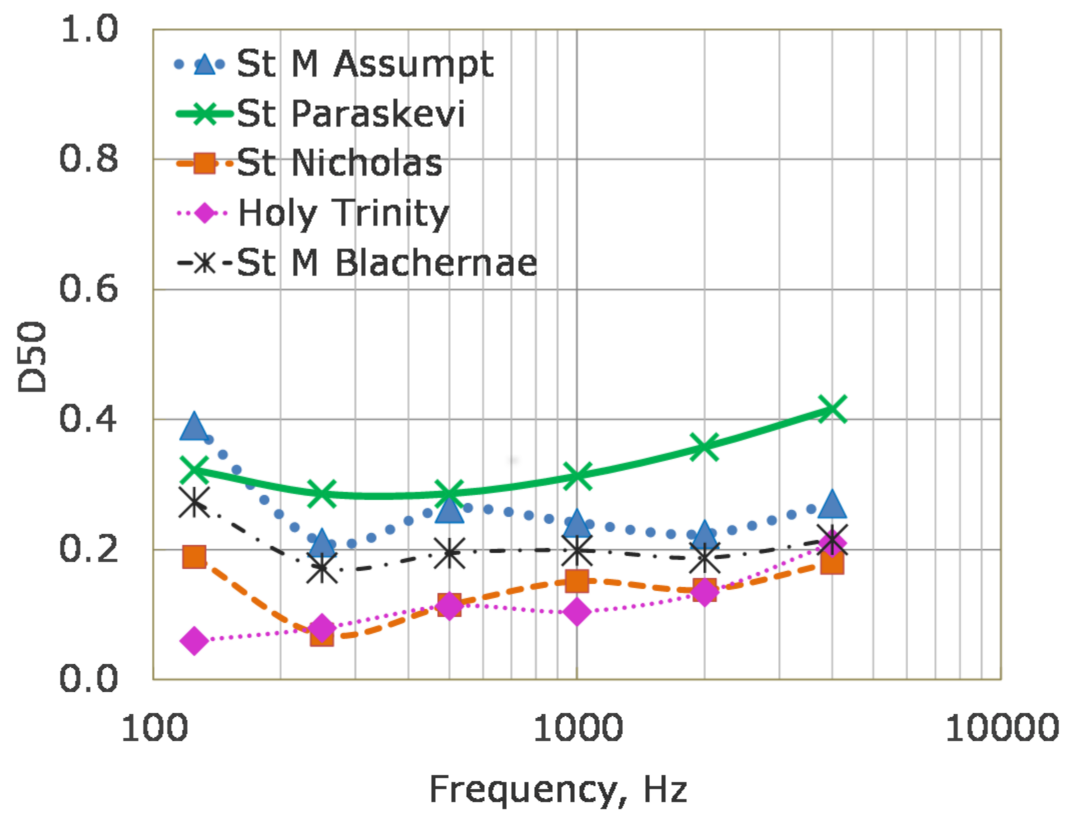

Figure 17. Measured results of definition $\left(D_{50}\right)$.

Figure 13 shows the EDT values based on the measurements undertaken inside each church. The graph indicates that St Nicholas's church has the highest EDT values, fluctuating between $1.8 \mathrm{~s}$ and $2.4 \mathrm{~s}$, corresponding to high and low frequencies, respectively. This outcome results in the optimal values outlined by Martellotta [41] for a good speech intelligibility. A similar volume shape, recalling the basilica, is represented by St Mary Assumption's, having an EDT trend line like that of St Nicholas's, but shifted below approximately $0.4 \mathrm{~s}$ at each octave [42]. Although St Mary Assumption's church has a volume size higher than St Nicholas's, the EDT results, comparable with the values found inside the St Mary Blachernae, were around 1.5 s [43]. This latest one has EDT values lower than Holy Trinity's church, although they have comparable room volumes; the only construction element that produces a difference of $0.2 \mathrm{~s}$ between the two rooms is the roof morphology, which is domed in the Holy Trinity's church. The EDT values measured inside St Paraskevi's were found to be the lowest, considering its room volume to be reasonably small and it is provided with a double slope roof.

Figure 14 shows that the trend lines of $\mathrm{T}_{20}$ are similar to the EDT curves, even if the $\mathrm{T}_{20}$ values shifted up to $0.2 \mathrm{~s}$ lower than the EDT values [44]. It should be noted how the measured values of $T_{20}$ inside St Mary Assumption's church are very comparable to those found in the Holy Trinity's church. It should be remembered that other factors contribute to the reverberation results inside a room, such as the height and shape of the roof and the intensity of reflection of the finish materials [45]. In St Nicholas's church, the plaster on the walls has been restored whereas in other churches this action has not been fulfilled. Therefore, the sound energy concentration contributes to the increase in the level of reverberation depending on geometry and architectural composition [46].

Audition 3.0 was employed to analyze the measured impulse responses (IRs) obtained inside St Nicholas's church, as shown in Figure 15. A concentration of sound energy was found after $80-100 \mathrm{~ms}$ from the direct sound; this is determined by the reflecting surfaces at the boundaries of the room that contribute to the build-up of the noise [47,48].

The speech transmission index (STI) was analyzed based on orations and prayers being the main activity functions inside the churches. Because STI reflects the levels of distortion of the speech signal due to reverberation and background noise levels, in all the churches it has been found to be "fair", as defined by the intelligibility rating according to ISO 9921 [49]. 
The ambient noise levels $\left(\mathrm{L}_{\text {Aeq }}\right)$ were measured in each church to assess the speech transmission index values, as summarized in Table 2.

Table 2. Measured ambient noise levels of the Albanian churches.

\begin{tabular}{ccccc}
\hline \multicolumn{5}{c}{ A-Weighted Equivalent Sound Pressure Levels L $_{\text {Aeq }}(\mathrm{dB})$} \\
\hline Assumpt. & St Parask. & St Nich. & Holy Trinity & Blachernae \\
\hline 38 & 41 & 40 & 42 & 39 \\
\hline
\end{tabular}

Figure 16 shows the results related to $C_{50}$, found in all the churches to be below the optimal target for speech comprehension $\left(-2<\mathrm{C}_{50}<+2 \mathrm{~dB}\right)$ [50]. This outcome reflects a fairly poor condition for the words' clarity. The worst $C_{50}$ value was recorded in the Holy Spirit's church to be up to $15 \mathrm{~dB}$ below the lower-range limit, accentuated mainly at low frequencies [51].

St Nicholas's church indicates having similar results, while the measured values that more approximate the optimal target are related to St Paraskevi's church, closer to $0 \mathrm{~dB}$ at high frequencies. St Mary Assumption's and St Mary Blachernae's have similar clarity response, fluctuating around $-6 \mathrm{~dB}$. The outcome of $\mathrm{C}_{50}$, found to have negative values in all the churches, is due to the reflections arriving at the receiver positions after $50 \mathrm{~ms}$ from the direct sound, as indicated in Figure 15. These late reflections are owed to the architectural elements, characterized by the curved surface of the vault and dome, where applicable.

In relation to the definition $\mathrm{D}_{50}$, the measured results are summarized in Figure 17. The results related to all the churches show the $\mathrm{D}_{50}$ values to be fluctuating between 0.1 and $0.4(10-40 \%)$. The best response is related to St Paraskevi's church, around 0.4 across all the frequency bands. St Nicholas's and Holy Trinity's churches have similar values in terms of definition, to be approximated to 0.1 at low frequencies and 0.2 at higher octaves, which is considered poor [52].

\section{Conclusions}

The Byzantine churches have always been studied from an architectural perspective, but none of the acoustic aspects have been analyzed. The authors' intention was to give some reference in relation to the level of speech understanding inside five selected churches, as prayers and orations are the main performed activities [53].

In all the churches, the reverberation time was found to be within or closer to the optimal values, except for the Holy Trinity's and the St Mary Blachernae's churches, where the reduced volume size determined the values that were measured.

The speech clarity index in all churches was found to be below the optimal range limits, accentuated widely in St Nicholas's and the Holy Trinity's churches. The measured values of $C_{50}$ that were found to be closer to the optimal target are related to St Paraskevi's church. A similar outcome was found for the $\mathrm{D}_{50}$ parameter.

The authors are aware of the limitations that this study had fundamentally, especially regarding the utilization of the balloon pops as a sound source. Although the uncertainties in relation to directivity, repeatability and spectrum bandwidth are known, this measuring method is extensively used, particularly in places where the electrical system is not available, as in so many cultural heritage buildings [54,55].

Acoustic simulations of these Byzantine churches would predict the acoustic measures that could potentially be applied to improve the listening conditions inside the churches. In addition, the list of other Byzantine churches to be acoustically measured, located in other cities of Albania, will be implemented. This will also involve the employment of different equipment, such as an omnidirectional sound source to be fed by an Exponential Sound Sweep (ESS), in order to cover a broaden bandwidth. 


\begin{abstract}
Author Contributions: Conceptualization, S.S., G.I. and A.T.; methodology, G.I., A.T. and I.L.; software, A.B., G.I. and I.L.; validation, A.B. and G.I.; formal analysis, A.B.; investigation, S.S., R.P. and G.I.; resources, S.S.; data curation, A.B., I.L. and R.P.; writing-original draft preparation, G.I., A.T., R.P. and S.S.; writing-review and editing, A.B.; visualization, A.B.; supervision, G.I. and A.T.; project administration, G.I., A.T. and S.S.; funding acquisition, G.I., A.T. and I.L. All authors have read and agreed to the published version of the manuscript.
\end{abstract}

Funding: This research received no external funding.

Institutional Review Board Statement: Not applicable.

Informed Consent Statement: Not applicable.

Data Availability Statement: Not applicable.

Acknowledgments: A special thanks goes to Arsim Murseli for the drawings and collaboration on the graphics of this manuscript.

Conflicts of Interest: The authors declare no conflict of interest.

\title{
References
}

1. Krausmuller, D. Emperors, patriarchs, metropolitans, deacons and monks: Individuals and groups in the Byzantine Church (6th 11th centuries). Scrinium 2021, 17, 199-238. [CrossRef]

2. Yastrebov, A. The liturgy of power. Some aspects of the religious policy of Venice in relation to the orthodox church in modern age. Istoriya 2021, 12. [CrossRef]

3. Belke, K. Roads and routes in northwestern and adjoining parts of central asia minor: From the romans to Byzantium, with some remarks on their fate during the ottoman period up to the 17th century. Gephyra 2020, 20, 79-98. [CrossRef]

4. Ozcan, Z. Greek Orthodox churches in Anatolia. Int. Ser. Adv. Arch. 1997, 3, 45-55.

5. Geanakoplos, D.J. Church and State in the Byzantine Empire: A Reconsideration of the Problem of Caesaropapism. Church Hist. 1965, 34, 381-403. [CrossRef]

6. Hussey, J.M. The Orthodox Church in the Byzantine Empire; OUP Oxford: Oxford, UK, 1986.

7. Megaw, H. The Chronology of Some Middle-Byzantine Churches. Annu. Br. Sch. Athens 1932, 32, 90-130. [CrossRef]

8. Hill, S. The Early Byzantine Churches of Cilicia and Isauria; Variorum: Aldershot, UK, 1996; p. 208.

9. Ballance, S. The Byzantine Churches of Trebizond. Anatol. Stud. 1960, 10, 141-175. [CrossRef]

10. Bikai, P.M. The Churches of Byzantine Petra. Near East. Archaeol. 2002, 65, 271-276. [CrossRef]

11. Fausti, P.; Pompoli, R.; Prodi, N. Comparing the Acoustics of Mosques and Byzantine Churches. In Proceedings of the 19th International Symposium CIPA, Antalya, Turkey, 30 September-4 October 2003.

12. Curcic, S. The role of late Byzantine Thessalonike in church architecture in the Balkans. Dumbart. Oaks Pap. 2003, 57, 65-84. [CrossRef]

13. ISO 3382-1; Acoustics-Measurement of Room Acoustic Parameters-Part 1: Performance Spaces. ISO: Geneva, Switzerland, 2009.

14. Dordevic, Z. Archaeoacoustic research of Ljubostinja and Naupara Medieval Monastic Churches. Open Archaeol. 2019, 5, $274-283$. [CrossRef]

15. Bilgin, H.; Demaj, A. Typological Classification of Post-Byzantine churches in Albania. In Proceedings of the 1st International Balkans Conference on Challenges of Civil Engineering (BCCCE), Tirana, Albania, 19-21 May 2011.

16. Krautheimer, R.; Curcic, S. Early Christian and Byzantine Architecture-Pelican History Art, 4th ed.; Yale University Press: New Haven, CT, USA, 1992.

17. Hamilton, J.A. Byzantine Architecture and Decoration, 2nd ed.; Batsford: London, UK, 1956.

18. Gjata, K.; Demaj, M.; Çuku, R. Architecture, Identity and Phases Of Construction of the Byzantine Church of St. Mary VllahernaBerat/Albania. In Proceedings of the International Conference on Architecture and Urban Design, Tirana, Albania, 19-21 April 2012.

19. Kokoli, S.; Klosi, I. The Byzantine Codices: Beratinus-1 \& Beratinus-2, Two Cultural Treasures from The City of Berat. from The Beginning-Today on the List of "Mémoire Du Monde", Unesco (Part I). Eur. J. Res. Reflect. Arts Humanit. 2016, 4, 76-88.

20. Gill, M.D. Civil engineering heritage: Country profile-Albania. Proc. Inst. Civ. Eng. Eng. Hist. Herit. 2016, 169, 147-150. [CrossRef]

21. Frazee, C.A. Catholics and Sultans: The Church and the Ottoman Empire 1453-1923; Cambridge University Press: Cambridge, UK, 2006.

22. Spatharakis, I. Dated Byzantine Wall Paintings of Crete; Alexandros Press: Leiden, The Netherlands, 2001 ; Volume 2.

23. Kalopissi-Verti, S. Church foundations by entire villages 13th-16th c.: A short note. Zbornik Radova Vizantoloskog Instituta 2007, 44, 333-340. [CrossRef]

24. Pavlidou, E.; Arapi, M.; Zorba, T.; Anastasiou, M.; Civici, N.; Stamati, F.; Paraskevopoulos, K.M. Onoufrios, the famous XVI's century iconographer, creator of the "Berati School": Studying the technique and materials used in wall paintings of inscribed churches. Appl. Phys. A 2006, 83, 709-717. [CrossRef] 
25. Kaffenberger, T. A Newly Discovered Church in Cyprus. Remarks on New Architectural Forms' Modes of Transmission in Sixteenth-Century Mediterranean. Convivium 2018, 5, 130-136. [CrossRef]

26. Zachariadou, E.A. Glances at the Greek Orthodox Priests in the Seventeenth Century. In Living in the Ottoman Ecumenical Community; Brill: Leiden, The Netherlands, 2008; pp. 307-316.

27. Shumka, L. Elemente të simbolikës së gjallesave në arkitekturën kristiane të Kishës së Shën Nikollës në Manastirin e Mesopotamit. Optime 2020, 12, 177-184. [CrossRef]

28. Snelders, B.; Jeudy, A. Guarding the entrances: Equestrian saints in Egypt and North Mesopotamia. East. Christ. Art 2006, 3, 105.

29. St. Nicholas (Mesopotam) Monastery. Available online: https://www.intoalbania.com/attraction/st-nicholas-mesopotammonastery (accessed on 28 January 2022).

30. Iannace, G.; Ciaburro, G.; Trematerra, A. The acoustics of the holy family church in Salerno. Can. Acoust. 2020, 48, 27-34.

31. Kodheli, E. Byzantine Churches in Berat and their Architectural Characteristics. Artum-Istorijsko-umetnički časopis 2017, 5, 6-12.

32. Palermo, A.; Diefendorf, B.C.; Muse, D.C.; Whitmore, Z.J. Disaster Risk Assessment of Cultural Heritage Sites in Berat, Albania; Cultural Heritage without Borders: Gjirokaster, Albania, 2017.

33. Qirici, K. Architectural Conservation in Albania and in other Countries of Europe. In Proceedings of the International Conference on Architecture and Urban Design, Tirana, Albania, 19-21 April 2012.

34. Peza, A. Albanian Icons, a Cultural Heritage Always in the "Target". Anglisticum J. Assoc. Inst. Engl. Lang. Am. Stud. 2019, 8 , 74-81.

35. Sukaj, S.; Lombardi, I.; Trematerra, A. The Acoustics of a Medieval Room. In Proceedings of the INTER-NOISE 2021-International Congress and Exposition of Noise Control Engineering, Washington, DC, USA, 1-5 August 2021.

36. Kokoli, S. The Medieval City of Berat and Iconography in the Post-Byzantine Period: A historical overview. Sch. J. Arts Humanit. Soc. Sci. 2015, 3, 881-887.

37. Pätynen, J.; Katz, B.F.G. Investigation on the balloon as an impulse source. J. Acoust. Soc. Am. 2011, 129, EL27-EL33. [CrossRef]

38. Gomez-Agustina, L.; Vazquez-Barrera, P. Repeatability of the balloon pop as a sound source in a room. In Proceedings of the Institute of Acoustics, London, UK, 5-9 October 2020; Volume 42.

39. Priyadharshini, V.; Vasupradaa, M.; Yeshoda, K. Acoustic analysis of voice of temple priests. In Proceedings of the 46th National Symposium on Ac (NSA), Aligarh, India, 28-30 October 2017.

40. Sotiropoulou, A.; Poulakos, G.; Panos, A.; Karagiannis, I.; Konstantopoulos, I. Acoustic measurements in orthodox churches of the Modern Greek Period. In Proceedings of the The 23rd International Congress on Sound and Vibration, Athens, Greece, 10-14 July 2016.

41. Martellotta, F. A multi-rate decay model to predict energy-based acoustic parameters in churches. J. Acoust. Soc. Am. 2009, 125, 1281-1284. [CrossRef] [PubMed]

42. Quartieri, J.; Mastorakis, N.E.; Guarnaccia, C.; Iannone, G. Church Acoustics Measurements and Analysis. In Proceedings of the 11th WSEAS International Conference on “Acoustics \& Music: Theory \& Applications" (AMTA'10), Iasi, Romania, 13-15 June 2010; pp. 216-224.

43. Cirillo, E.; Martellotta, F. Acoustics of apulian-romanesque churches: Correlation between architectural and acoustic parameters. Build. Acoust. 2003, 10, 55-76. [CrossRef]

44. Cirillo, E.; Martellotta, F. On the Spatial Variation of Acoustical Parameters in Churches. In Proceedings of the International Congress on Acoustics, Madrid, Spain, 2-7 September 2007.

45. Tsilfidis, A.; Papadakos, C.; Kokkinis, E.; Chryssochoidis, G.; Delviniotis, D.; Kouroupetroglou, G.; Mourjopoulos, J. Reverberation and deverberation effect on Byzantine chants. In Proceedings of the 135th Audio Engineering Society Convention, New York, NY, USA, 17-20 October 2013; p. 8977.

46. Tzekakis, E.G. Reverberation time of the Rotunda of Thessaloniki. J. Acoust. Soc. Am. 1975, 57, 1207-1209. [CrossRef]

47. Martellotta, F.; Cirillo, E.; Carbonari, A. Guidelines for acoustical measurements in churches. Appl. Acoust. 2009, 70, 378-388. [CrossRef]

48. Cirillo, E.; Martellotta, F. Sound propagation and energy relations in churches. J. Acoust. Soc. Am. 2005, 118, 232-248. [CrossRef]

49. ISO 9921; Ergonomics-Assessment of Speech Communication; ISO: Geneva, Switzerland, 2003.

50. Giron, S.; Alvarez-Morales, L.; Zamarreno, T. Church acoustics: A state-of-the-art review after several decades of research. J. Sound Vib. 2017, 411, 378-408. [CrossRef]

51. Peer, I.; Rafaely, B.; Zigel, Y. Room Acoustics Parameters Affecting Speaker Recognition Degradation Under Reverberation. In Proceedings of the 2008 Hands-Free Speech Communication and Microphone Arrays (HSCMA), Trento, Italy, 6-8 May 2008; pp. 136-139.

52. Thiele, R. Richtungsverteilungs und zeitfolge del schallruckewurfe in raumen. Acta Acust. 1953, 3, $291-302$.

53. Puetz, V.M.A. Articulation los of consonants as a criterion for speech transmission in a room. J. Audio Eng. Soc. 1971, 19, 915-919.

54. Carvalho, A.P.O.; Morgado, A.E.J.; Henrique, L. Relationship between subjective and objective acoustical measures in churches. Build. Acoust. 1997, 4, 1-20. [CrossRef]

55. Merli, F.; Bevilacqua, A. Using a Church as a Temporary Auditorium. Acoustical Design of S. Domenico of Imola. J. Phys. Conf. Ser. 2020, 1655, 012146. [CrossRef] 